\title{
PENGARUH LEVERAGE, FIXED ASSET INTENSITY, DAN FIRM SIZE TERHADAP NILAI PERUSAHAAN DENGAN REVALUASI ASET SEBAGAI MODERASI
}

\author{
Rizki Meirdiani Lestari ${ }^{1)}$; Indarto ${ }^{2)}$ \\ rizkimeirdiani@gmail.com ${ }^{1)}$; indarto@usm.ac.id ${ }^{2)}$
}

Program Studi Magister Manajemen, Universitas Semarang, Semarang, Indonesia

\section{Info Artikel \\ Sejarah Artikel: \\ Diterima : 9-10-2018 \\ Disetujui : 17-10-2018 \\ Dipublikasikan : 07-04- \\ 2019}

Keywords:

fixed Assets intensity;

firm size; leverage;

firmvalue; revaluation.

\begin{abstract}
Abstrak
Penelitian ini bertujuan untuk menganalisis pengaruh leverage yang diproksikan dengan debt to asset ratio, fixed asset intensity dan firm size terhadap nilai perusahaan yang diproksikan dengan price to book value dengan revaluasi aset sebagai moderasi. Data diambil dari laporan keuangan dan laporan tahunan perusahaan manufaktur yang terdaftar di BEI tahun 2015-2016. Dengan metode purposive sampling, diperoleh 42 sampel perusahaan revaluer. Data diolah menggunakan analisis SEM smartPLS versi 3.0 Hasil pengujian menunjukkan bahwa leverage dan firm size berpengaruh signifikan terhadap nilai perusahaaan, sedangkan fixed asset intensity tidak berpengaruh terhadap nilai perusahaan. Revaluasi aset tidak memoderasi hubungan antara leverage, fixed asset intensity dan firm size terhadap nilai perusahaan.
\end{abstract}

\section{INFLUENCE OF LEVERAGE, FIXED ASSET INTENSITY, AND FIRM SIZE TO THE FIRM VALUE WITH REVALUATION OF FIXED ASSETS AS A MODERATING}

\begin{tabular}{|c|c|}
\hline \multicolumn{2}{|c|}{ Abstract } \\
\hline & $\begin{array}{l}\text { The purpose of this study is to analyze the influence of leverage which using debt to } \\
\text { asset ratio as the proxy, fixed asset intensity and firm size to the firm value which } \\
\text { using price to book value as the proxy with revaluation of fixed assets as a } \\
\text { moderating.The data obtained from the financial statements and annual report of } \\
\text { manufacturing companies that listed in the Indonesian Stock Exchange on period } \\
2015-2016 \text {. As much as } 42 \text { revaluer firms were taken as a sample using purposive } \\
\text { sampling method, ande analyzed by the Structural Equatiom Modeling (SEM) } \\
\text { analysis using smartPLS version 3.0.The results shows that leverage and firm size } \\
\text { significantly effect to the firm value, but fixed asset intensity has not significant } \\
\text { effect to the firm value. As a moderating variable, revaluation of fixed assets can } \\
\text { not moderate the effect of leverage, fixed asset intensity and firm size to the firm } \\
\text { value. }\end{array}$ \\
\hline${ }^{\otimes}$ Alamat korespondensi & 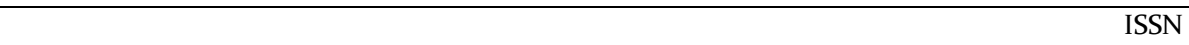 \\
\hline Magister Manajemen, $\mathrm{C}$ & versitas Semarang, Jl Sukarno Hatta, Semarang \\
\hline E-mail: indarto@usm.a & $2580-8451$ (online) \\
\hline
\end{tabular}




\section{PENDAHULUAN}

Persaingan bisnis pada era globalisasi saat ini berkembang pesat, sehingga muncul tuntutan kepada setiap perusahaan untuk terus meningkatkan kinerja agar dapat menarik minat investor untuk berinvestasi pada perusahaannya. Hal tersebut dikarenakan perusahaan memerlukan dana tambahan dari pihak eksternal untuk mempertahankan going concern nya. Jumlah perusahaan go public yang terus meningkat menunjukkan tingginya persaingan bisnis, sehingga perusahaan harus semakin bersaing untuk mencapai tujuan utama perusahaan. Menurut theory of the firm, tujuan utama perusahaan adalah memaksimalkan nilai perusahaan, yang artinya memaksimalkan kemakmuran pemegang saham, dalam hal ini diartikan sebagai memaksimalkan harga saham perusahaan. Meskipun perusahaan memiliki tujuan yang berbeda-beda, namun memaksimalkan harga saham adalah tujuan yang paling penting dari suatu perusahaan (Brigham dan Houston, 2010).

Nilai perusahaan merupakan persepsi investor terhadap tingkat keberhasilan perusahaan yang terkait erat dengan harga sahamnya, dimana harga saham yang tinggi mengindikasikan nilai perusahaan yang tinggi (Sujoko dan Subiantoro, 2007). Perusahaan yang memiliki nilai perusahaan tinggi akan menumbuhkan rasa kepercayaan dari pihak-pihak terkait dengan perusahaan tersebut maupun dari masyarakat luas. Hal ini dikarenakan nilai perusahaan yang tinggi menunjukkan bahwa kinerja perusahaan baik. Bagi perusahaan go public, nilai pasar wajar ditentukan oleh mekanisme permintaan dan penawaran di bursa, yang dapat dilihat pada listing price (Suharli, 2006).

Untuk meningkatan nilai perusahaan, diperlukan kerjasama antara manajemen dengan pemegang saham dalam mengambil kebijakan keuangan. Dalam agency theory digambarkan hubungan antara agen dan principal. Pihak manajer sebagai agen harus dapat menjalankan perusahaan dengan berbagai pengambilan keputusan terbaik untuk meningkatkan kekayaan pihak principal yaitu pemegang saham. Kadangkala pemegang saham tidak dapat mengawasi semua keputusan dan kegiatan pihak manajemen, sehingga akan menimbulkan ancaman ketika yang dilakukan oleh manajer bukan untuk kesejahteraan pemegang saham, namun justru untuk kesejahteraan mereka sendiri. Inilah yang kemudian menjadi masalah dasar dalam agency theory, yaitu adanya konflik kepentingan atau konflik agensi (Rahayu dan Sari, 2018)

Ketidakberhasilan untuk memaksimalkan nilai perusahaan juga dapat disebabkan oleh faktor internal maupun eksternal perusahaan. Faktor eksternal dapat berupa tingkat bunga, fluktuasi nilai valas dan keadaan pasar modal. Sedangkan faktor internal antara lain ukuran perusahaan, risiko keuangan, nilai aktiva, pertumbuhan dan pembayaran deviden. (Rahmawati, 2002, dalam Analisa 2011). Menurut Brigham dan Houston (2010), nilai perusahaan dipengaruhi oleh beberapa faktor, yaitu : rasio likuiditas, rasio manajemen aset, rasio manajemen hutang (leverage), dan rasio profitabilitas.

Kebijakan hutang merupakan salah satu faktor yang dapat menjadi pertimbangan investor dalam melakukan penilaian terhadap perusahaan tersebut. Dalam trade off theory dijelaskan bahwa semakin besar perusahaan menggunakan pendanaan dengan hutang, maka semakin besar pula risiko perusahaan untuk mengalami kesulitan keuangan (Rahayu dan Sari, 2018). Perusahaan dengan tingkat hutang yang tinggi 
memiliki risiko investasi yang tinggi pula. Risiko perusahaan yang tinggi tersebut akan menyebabkan investor lebih berhati-hati dalam berinvestasi. Jumlah hutang yang terlalu tinggi akan menimbulkan risiko financial distress, sehingga nilai perusahaan akan menurun (Sujoko dan Soebiantoro, 2007).

Semakin besar ukuran perusahaan, maka akan semakin mudah pula bagi perusahaan untuk memperoleh sumber pendanaan baik dari internal maupun eksternal. Besar kecilnya ukuran suatu perusahaan dapat didasarkan pada total nilai aktiva, total penjualan, kapitalisasi pasar, jumlah tenaga kerja dan sebagainya. Menurut Hilmi dan Ali (2008) dalam Khairati et al (2015), semakin besar aktiva suatu perusahaan maka akan semakin besar pula modal yang ditanamkan dalam perusahaan tersebut, semakin besar total penjualan suatu perusahaan maka akan semakin banyak juga perputaran uang dalam perusahaan tersebut, dan semakin besar kapitalisasi pasar maka akan semkin besar pula perusahaan tersebut dikenal oleh masyarakat.

Aset tetap dalam perusahaan memiliki peranan yang cukup besar dalam mendukung kegiatan operasional perusahaan. Nilai investasi yang ditanamkan dalam aset tetap relatif besar serta aset tetap merupakan harta perusahaan yang menyerap sebagian besar modal perusahaan, karena dari segi jumlah dana untuk memperoleh aset tetap diperlukan dana yang relatif besar (Ernawati, 2014, dalam Dharmendra, 2016). Perusahaan yang proporsi aset tetapnya besar diharapkan dapat memaksimalkan produktivitas yang akan meningkatkan laba perusahaan di masa yang akan datang, yang tentu saja akan mempengaruhi nilai perusahaan tersebut di mata investor.

Data empiris terkait variabel yang digunakan dalam penelitian ini yaitu debt to asset ratio, fixed asset intensity. firm size, dan PBV sebagai berikut :

Tabel 1.1

Rata-Rata Nilai Debt to Asset Ratio (DAR), Fixed Asset Intensity, Firm Size, dan Price Book Value Perusahaan Manufaktur Terdaftar di Bursa Efek Indonesia (BEI) Tahun 2015-2016

\begin{tabular}{|c|c|c|}
\hline Variabel & $\mathbf{2 0 1 5}$ & $\mathbf{2 0 1 6}$ \\
\hline DAR (\%) & 48,29 & 48,90 \\
\hline Fixed Asset Intensity (\%) & 36,31 & 38,31 \\
\hline SIZE (Miliar Rp) & 7.995 & 8.511 \\
\hline PBV & 4,06 & 3,81 \\
\hline
\end{tabular}

Sumber : $\underline{w w w . i d x . c o . i d}$, data yang diolah 2018

Beberapa penelitian terdahulu memberikan hasil yang kontradiksi (research gap), sehingga dalam penelitian ini ditambahkan revaluasi aset sebagai moderasi. Revaluasi atau penilaian kembali aset perusahaan diakibatkan adanya kenaikan nilai aset di pasaran atau rendahnya nilai aset dalam laporan keuangan yang disebabkan oleh devaluasi atau sebab lain, sehingga nilai aset dalam laporan keuangan tidak lagi mencerminkan nilai wajar (Katuuk, 2013). Informasi yang lengkap, relevan, akurat dan tepat waktu sangat dibutuhkan oleh investor sebagai alat analisis dalam pengambilan keputusan investasi. Menurut Ross (1977) dalam Dharmendra (2016), informasi akuntansi yang diberikan perusahaan memberikan signal bahwa perusahaan mempunyai prospek yang baik di masa mendatang, sehingga investor tertarik untuk melakukan perdagangan saham dan pasar akan bereaksi yang tercermin melalui perubahan volume perdagangan saham. 
Menurut Mansur dan Wardoyo dalam Firmansyah dan Sherlita (2012), alasan perusahaan merevaluasi aktiva tetap tidak hanya menyajikan laporan keuangan menjadi lebih relevan dalam pengambilan keputusan, namun juga meningkatkan nilai perusahaan, sehingga memudahkan perusahaan dalam proses pencarian dana melalui pinjaman bank maupun penjualan saham perusahaan, serta meningkatkan beban aktiva tetap perusahaan pada masa yang akan datang sehingga beban pajak menjadi semakin kecil.

Penelitian ini mengambil objek perusahaan manufaktur yang terdaftar di BEI periode tahun 2015-2016. Perusahaan manufaktur memiliki karakteristik proses produksi yang tidak terputus, mulai dari pembelian bahan baku, pengolahan sampai menjadi produk siap jual yang dilakukan sendiri oleh perusahaan tersebut, sehingga sumber dana yang ada akan terikat lama pada aktiva tetapnya, serta proporsi aset tetapnya relatif lebih besar dibandingkan perusahaan sektor lainnya.

\section{TELAAH PUSTAKA}

\section{Pengaruh Leverage Terhadap Nilai Perusahaan}

Sebuah perusahaan dikatakan tidak solvable apabila total hutang perusahaan lebih besar daripada total aset yang dimiliki oleh perusahaan. Leverage merupakan kebijakan pendanaan yang berkaitan dengan keputusan perusahaan dalam membiayai perusahaan tersebut. Perusahaan yang menggunakan hutang (external fianancing) mempunyai kewajiban atas beban bunga dan beban pinjaman yang kemudian timbul, sehingga memiliki risiko cukup besar atas tidak terbayarnya hutang tersebut. Oleh karena itu, penggunaan hutang juga perlu memperhatikan kemampuan perusahaan dalam menghasilkan laba (Prasetyorini, 2013).

Dalam pecking order theory yang dikemukakan oleh Myers dan Majluf (1984) dijelaskan mengapa perusahaan profitable umumnya menggunakan hutang dalam jumlah sedikit. Perusahaan yang kurang profitable cenderung menggunakan hutang yang lebih besar karena dua alasan, yaitu tidak mencukupinya internal financing dan hutang merupakan sumber eksternal yang lebih disukai. Semakin tinggi rasio leverage menunjukkan semakin besarnya dana yang disediakan oleh kreditur (Weston dan Copeland, 2010 dalam Dharmendra, 2016). Investor akan lebih berhati-hati untuk berinvestasi pada perusahaan dengan leverage tinggi, karena semakin tinggi rasio leverage maka semakin tinggi pula risiko investasinya. Jumlah hutang yang terlalu tinggi akan menimbulkan risiko financial distress, sehingga nilai perusahaan akan menurun. Hasil penelitian yang dilakukan oleh Sujoko dan Soebiantoro (2007), Azari dan Fachrizal (2017) menunjukkan bahwa leverage berpengaruh signifikan terhadap nilai perusahaan. Berdasarkan uraian tersebut, maka diajukan hipotesis sebagai berikut :

H1 : Leverage berpengaruh terhadap nilai perusahaan.

\section{Pengaruh Fixed Asset Intensity Terhadap Nilai Perusahaan}

Intensitas aset tetap menggambarkan banyaknya investasi perusahaan terhadap aset tetap. Peranan aset tetap dalam mendukung kegiatan operasional perusahaan cukuplah besar. Nilai investasi yang ditanamkan oleh perusahaan pada aset tetap relatif besar, atau dapat dikatakan bahwa aset tetap merupakan harta perusahaan yang menyerap sebagian besar modal perusahaan. (Ernawati, 2014, dalam Dhaemendra, 2016). Intensitas aset tetap merepresentasikan proporsi aset tetap dibandingkan total 
aset perusahaan. Menurut Piera (2007), proporsi aset tetap yang besar diharapkan akan meningkatkan laba perusahaan di masa mendatang yang tentunya akan mempengaruhi nilai perusahaan. Penelitian Dharmendra (2016) menunjukkan bahwa fixed asset intensity berpengaruh positif terhadap nilai perusahaan. Berdasarkan uraian tersebut, maka diajukan hipotesis sebagai berikut :

$\mathrm{H} 2$ : Fixed asset intensity berpengaruh terhadap nilai perusahaan.

\section{Pengaruh Firm Size Terhadap Nilai Perusahaan}

Signaling theory menyatakan bahwa pasar akan mau membayar lebih mahal untuk mendapatkan sahamnya karena percaya akan mendapatkan pengembalian yang menguntungkan dari perusahaan tersebut. Semakin besar ukuran perusahaan maka ada kecenderungan lebih banyak investor yang menaruh perhatian pada perusahaan tersebut. Hal ini dikarenakan perusahaan besar cenderung memiliki kondisi yang lebih stabil, sehingga akan lebih menarik minat investor untuk memiliki saham perusahaan tersebut (Dharmendra, 2016). Kondisi tersebut menjadi penyebab naiknya harga saham perusahaan di pasar modal.

Investor memiliki ekspektasi yang besar terhadap perusahaan dengan ukuran besar yang berupa perolehan dividen. Peningkatan permintaan saham akan memacu naiknya harga saham perusahaan di pasar modal, dan menunjukkan bahwa perusahaan dianggap memiliki nilai yang lebih besar. Hal ini sesuai dengan hasil penelitian yang dilakukan oleh Prasetyorini (2013) dalam Pratama dan Wiksuana (2016), yang menyatakan bahwa ukuran perusahaan memiliki pengaruh positif signifikan terhadap nilai suatu perusahaan. Berdasarkan uraian tersebut, maka diajukan hipotesis sebagai berikut :

H3 : Firm size berpengaruh terhadap nilai perusahaan.

\section{Revaluasi Aset Memoderasi Pengaruh Leverage Terhadap Nilai Perusahaan}

Debt to Asset Ratio (DAR) merupakan perbandingan antara total hutang dengan total aktiva. Ketika tingkat hutang perusahaan meningkat, sementara proporsi total aktivanya tidak berubah, menunjukkan bahwa hutang perusahaan semakin besar dibandingkan kekayaan yang dimiliki oleh perusahaan. Semakin tinggi tingkat hutang perusahaan, semakin tinggi pula risiko yang ada. Jumlah hutang yang terlalu tinggi akan menimbulkan risiko financial distress, sehingga akan mengakibatkan menurunnya nilai perusahaan. Hal tersebut akan membuat perusahaan kesulitan dalam mencari dana tambahan melalui pinjaman pihak ketiga (kreditor) maupun penjualan saham.

Teori akuntansi positif Watts dan Zimmerman (1986) menyatakan bahwa manajer perusahaan dengan leverage yang tinggi, terutama dekat dengan pelanggaran perjanjian hutang, akan termotivasi untuk menggunakan metode akuntansi yang memungkinkan perusahaan untuk menghindari pelanggaran perjanjian hutang. Menurut Azouzi dan Jarboui (2012), revaluasi aset tetap dapat digunakan sebagai sarana untuk menurunkan debt ratio dan sebagai sinyal adanya pertumbuhan kemampuan perusahaan. Hasil penelitian Courtney dan Cahan (2000) menunjukkan bahwa revaluasi aktiva tetap berpengaruh positif terhadap return saham. Berdasarkan uraian tersebut, maka diajukan hipotesis sebagai berikut:

H4 : Revaluasi aset memoderasi pengaruh leverage terhadap nilai perusahaan.

\section{Revaluasi Aset Memoderasi Pengaruh Fixed Asset Intensity Terhadap Nilai Perusahaan}


Perusahaan dengan proporsi aset tetap yang tinggi diharapkan mampu memaksimalkan produktivitas yang akan meningkatkan laba di masa mendatang yang tentunya akan mempengaruhi nilai perusahaan. Aset tetap yang dinilai berdasarkan harga perolehan dan kemudian disusutkan selama masa manfaat aset, tidak lagi mencerminkan nilai aset yang sebenarnya atau dengan kata lain nilai aset kehilangan relevansinya. Oleh karena itu, perusahaan dengan proporsi aset tinggi akan melakukan revalusi aset untuk menyajikan nilai kekayaaan perusahaan yang sebenarnya.

Revaluasi yang mengakibatkan peningkatan nilai aset, akan memunculkan biaya depresiasi yang merupakan sumber dana internal perusahan, yang dapat digunakan untuk membagikan dividen kepada investor dan membayar hutang. Dalam jangka panjang, perusahaan juga mendapatkan manfaat perpajakan atas biaya depresiasi yang dapat dijadikan sebagai pengurang laba kena pajak perusahaan. Oleh karena itu, perusahaan dengan intensitas aset tetap tinggi cenderung memilih metode pengakuan aset yang dapat mencerminkan nilai aset perusahaan yang sesungguhnya. Berdasarkan uraian tersebut, maka diajukan hipotesis sebagai berikut:

H5 : Revaluasi aset memoderasi pengaruh fixed asset intensity terhadap nilai perusahaan.

\section{Revaluasi Aset Memoderasi Pengaruh Firm Size Terhadap Nilai Perusahaan}

Ukuran perusahaan menjadi faktor yang perlu dipertimbangkan dalam menilai perusahaan. Semakin besar ukuran perusahaan maka ada kecenderungan lebih banyak investor yang menaruh perhatian pada perusahaan tersebut. Hal ini dikarenakan perusahaan besar cenderung memiliki kondisi yang lebih stabil, sehingga akan lebih menarik minat investor untuk memiliki saham perusahaan tersebut (Dharmendra, 2016).

Berdasarkan positive accounting theory, ukuran perusahaan sering digunakan sebagai proksi dari political factor. Perusahaan besar cenderung memiliki profitabilitas tinggi. Ketika perusahaan melaporkan profitabilitas yang tinggi, laporan tersebut akan menarik perhatian pihak eksternal, seperti pemerintah dan serikat pekerja, dan akan mengakibatkan munculnya tuntutan-tuntutan politik. Menurut Seng dan Su (2010), perusahaan besar akan menghindari pelaporan profitabilitas yang tinggi untuk menurunkan tekanan politik dari pihak-pihak eksternal. Revaluasi aset yang mengakibatkan peningkatan nilai aset merupakan cara yang efektif untuk menurunkan pelaporan laba perusahaan melalui peningkatan biaya depresiasi. Berdasarkan uraian tersebut, maka diajukan hipotesis sebagai berikut:

H6 : Revaluasi aset memoderasi pengaruh firm size terhadap nilai perusahaan.

\section{Kerangka Pemikiran Teoritis}

Pengaruh leverage, fixed asset intensity, dan firm size terhadap nilai perusahaan dengan revaluasi aset tetap sebagai moderasi dapat digambarkan dalam kerangka pemikiran teoritis sebagai berikut : 


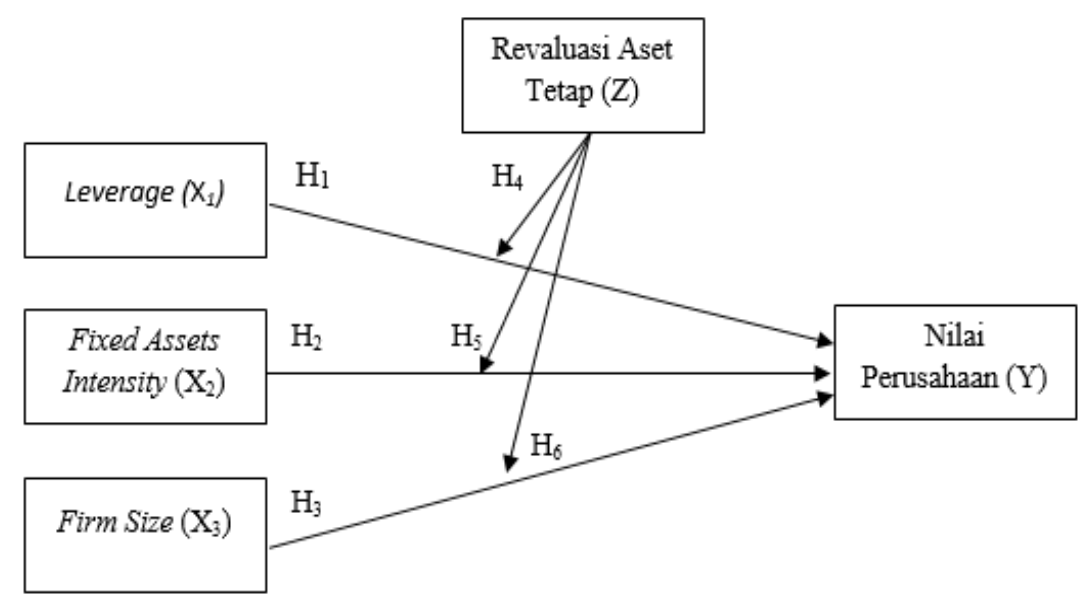

Gambar 1.1

Kerangka Pemikiran Teoritis

\section{METODE}

Data sekunder yang digunakan dalam penelitian ini berupa laporan keuangan dan laporan tahunan perusahaan, yang diperoleh dari Indonesian Capital Market Directory (ICMD) dan company report yang diperoleh dari Indonesia Stock Exchange (IDX). Populasi penelitian adalah perusahaan manufaktur yang terdaftar di BEI berturut-turut tahun 2015-2016. Tehnik pengambilan sampel menggunakan metode purposive sampling, dengan kriteria sampel penelitian sebagai berikut :

Tabel 1.2

Hasil Pemilihan Sampel Penelitian

\begin{tabular}{|l|c|c|}
\hline \multicolumn{1}{|c|}{ Kriteria } & 2015 & $\mathbf{2 0 1 6}$ \\
\hline $\begin{array}{l}\text { Perusahaan manufaktur yang terdaftar di BEI berturut- } \\
\text { turut tahun 2015-2016 }\end{array}$ & 143 & 143 \\
\hline $\begin{array}{l}\text { Perusahaan manufaktur yang melakukan upward } \\
\text { revaluation }\end{array}$ & 30 & 23 \\
\hline $\begin{array}{l}\text { dikeluarkan : karena tidak memakai satuan mata uang } \\
\text { Rupiah dalam laporan keuangannya }\end{array}$ & (4) & (4) \\
\hline $\begin{array}{l}\text { dikeluarkan : karena tidak tersedianya data yang } \\
\text { dibutuhkan untuk variabel penelitian }\end{array}$ & $\mathbf{2 3}$ & $\mathbf{1 9}$ \\
\hline Jumlah sampel akhir & $(3)$ & - \\
\hline
\end{tabular}

Sumber : data yang diolah, 2018 


\section{Definisi Operasional Variabel}

Definisi operasional variabel penelitian dapat diidentifikasikan sebagai berikut:

Tabel 1.3

Definisi Operasional Variabel

\begin{tabular}{|c|c|l|c|}
\hline No & Variabel & \multicolumn{1}{|c|}{ Definisi Operasional } & Pengukuran \\
\hline 1. & $\begin{array}{c}\text { Debt to Asset } \\
\text { Ratio (DAR) }\end{array}$ & $\begin{array}{l}\text { Rasio antara total hutang terhadap } \\
\text { total aktiva }\end{array}$ & $\frac{\text { Total liabilitas }}{\text { Total aset }}$ \\
\hline 2. & $\begin{array}{c}\text { Fixed Assets } \\
\text { Intensity } \\
\text { (FAI) }\end{array}$ & $\begin{array}{l}\text { Proporsi aset perusahaan yang } \\
\text { terdiri dari aktiva tetap }\end{array}$ & $\frac{\text { Total aset tetap }}{\text { Total aset }}$ \\
\hline $3 \cdot$ & Firm Size & $\begin{array}{l}\text { Total aset perusahaan yang dimiliki } \\
\text { pada akhir periode tahun buku. }\end{array}$ & Ln Total aset \\
\hline 4. & $\begin{array}{c}\text { Price to Book } \\
\text { Value (PBV) }\end{array}$ & $\begin{array}{l}\text { Rasio antara harga pasar saham } \\
\text { akhir tahun dengan nilai buku } \\
\text { perusahaan }\end{array}$ & $\frac{\text { Closing price }}{\text { Nilai buku }}$ \\
\hline 5. & Revaluasi aset & $\begin{array}{l}\text { Penilaian kembali aset tetap } \\
\text { perusahaan }\end{array}$ & $\begin{array}{c}\text { Ln Selisih penilaian } \\
\text { kembali aktiva }\end{array}$ \\
\hline
\end{tabular}

\section{Metode Analisis}

Untuk menguji pengaruh variabel penentu (leverage, fixed asset intensity, dan firm size) terhadap nilai perusahaan dengan revaluasi aset sebagai variabel moderating, maka model panel data dalam penelitian ini dirumuskan sebagai berikut :

$$
\begin{aligned}
\mathrm{PBV}= & \beta_{1} \text { DAR }+\beta_{2} \text { FAI }+\beta_{3} \text { SIZE }+\beta_{4} \text { DAR.REV }+\beta_{5} \text { FAI.REV }+ \\
& \beta_{6} \text { SIZE.REV }+\varepsilon_{1}
\end{aligned}
$$

\section{dimana :}

$$
\begin{array}{ll}
\text { PBV } & : \text { Price to Book Value } \\
\beta & : \text { Parameter } \\
\text { DAR } & : \text { Debt to Asset Ratio } \\
\text { FAI } & : \text { Fixed Asset Intensity } \\
\text { SIZE } & : \text { Firm Size } \\
\varepsilon & : \text { error / nilai residual regresi }
\end{array}
$$


HASIL DAN PEMBAHASAN

Tabel 1.4

Statistik Deskriptif

\begin{tabular}{cccccccc}
\hline & Mean & Median & Min & Max & SD & $\begin{array}{c}\text { Kurtosi } \\
\text { s }\end{array}$ & Skewness \\
\hline DAR & 0,476 & 0,507 & 0,041 & 0,885 & 0,251 & -1.240 & -0.083 \\
\hline FAI & 0,375 & 0,397 & 0,000 & 0,775 & 0,202 & -0.778 & 0.161 \\
\hline SIZE & 28,209 & 27,919 & 25,295 & 33,134 & 1,597 & 0.844 & 0.787 \\
\hline REV & 25,880 & 26,050 & 22,508 & 29,065 & 1,498 & -0.251 & -0.107 \\
\hline PBV & 1,277 & 0,850 & 0,120 & 6,010 & 1,129 & 5.908 & 2.002 \\
\hline \multicolumn{7}{l}{ Sumber : data yang diolah, 2018 }
\end{tabular}

Tabel 1.5

Uji Hipotesis

\begin{tabular}{|c|c|c|c|c|c|c|c|}
\hline & & & $\begin{array}{c}\text { Original } \\
\text { Sample } \\
(0)\end{array}$ & $\begin{array}{c}\text { Sample } \\
\text { Mean } \\
\text { (M) }\end{array}$ & $\begin{array}{l}\text { Standard } \\
\text { Deviation } \\
\text { (STDEV) }\end{array}$ & $\begin{array}{c}\text { T Statistics } \\
(|\mathrm{O} / \mathrm{STDEV}|)\end{array}$ & $\begin{array}{c}\mathbf{P} \\
\text { Values }\end{array}$ \\
\hline DAR & $\rightarrow$ & $\begin{array}{l}\text { PB } \\
\text { V }\end{array}$ & -0.392 & -0.359 & 0.192 & 2.045 & 0.041 \\
\hline FAI & $\rightarrow$ & $\begin{array}{l}\mathrm{PB} \\
\mathrm{V}\end{array}$ & -0.163 & -0.168 & 0.151 & 1.083 & 0.279 \\
\hline SIZE & $\rightarrow$ & $\begin{array}{l}\text { PB } \\
\text { V }\end{array}$ & 0.893 & 0.829 & 0.274 & 3.254 & 0.001 \\
\hline REV & $\rightarrow$ & $\begin{array}{l}\mathrm{PB} \\
\mathrm{V}\end{array}$ & -0.192 & -0.127 & 0.229 & 0.839 & 0.402 \\
\hline \multicolumn{2}{|c|}{$\begin{array}{c}\text { REV.DAR - } \\
\text { PBV }\end{array}$} & $\rightarrow$ & 0.043 & 0.062 & 0.152 & 0.285 & 0.776 \\
\hline \multicolumn{2}{|c|}{$\begin{array}{c}\text { REV.FAI } \\
\text { PBV }\end{array}$} & $\rightarrow$ & 0.001 & -0.061 & 0.249 & 0.004 & 0.997 \\
\hline \multicolumn{2}{|c|}{$\begin{array}{c}\text { REV.SIZE } \\
\text { PBV }\end{array}$} & $\rightarrow$ & -0.241 & -0.164 & 0.268 & 0.897 & 0.370 \\
\hline
\end{tabular}

Sumber : data yang diolah, 2018 


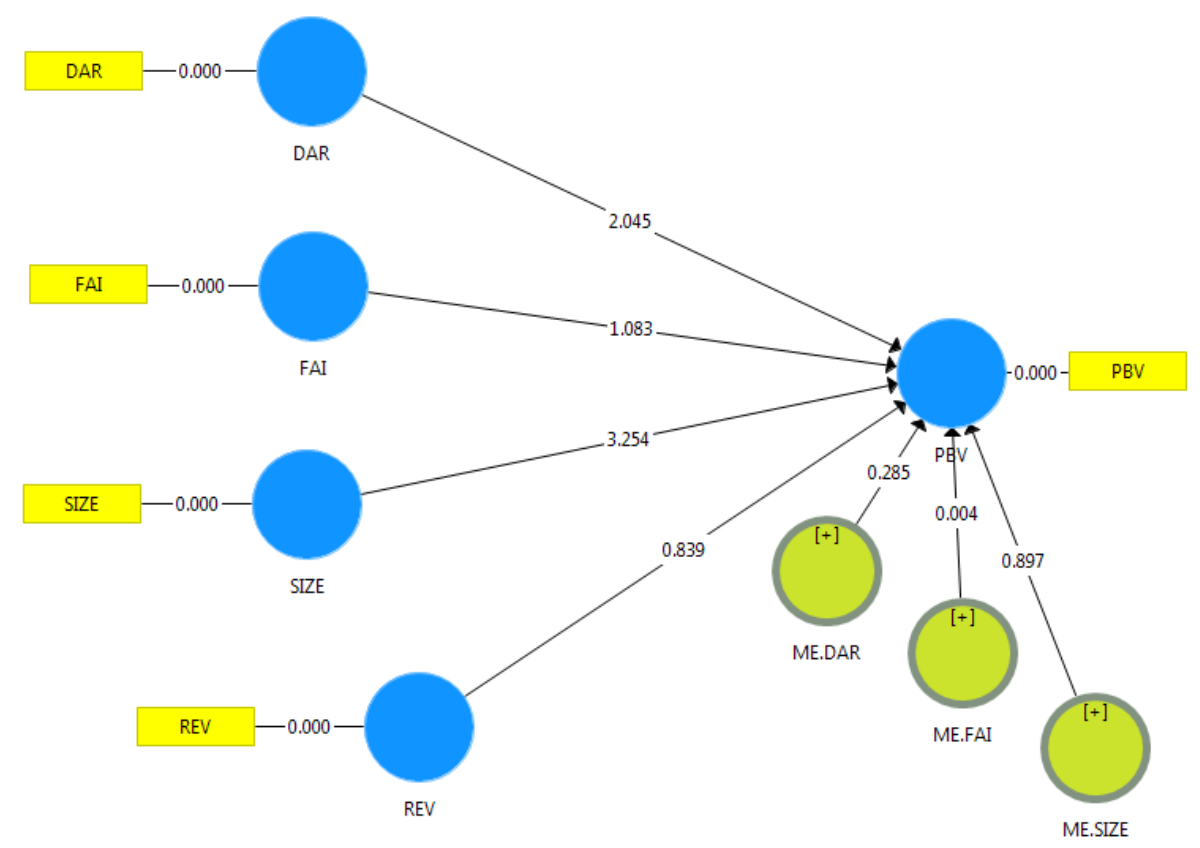

Gambar 1.2

Tampilan Output PLS Bootstrapping

\section{Pengujian Hipotesis \\ Pengujian Hipotesis 1}

Pengujian hubungan variabel DAR terhadap PBV menunjukkan nilai O.S negatif sebesar 0,392 , nilai t-statistik sebesar 2,045 lebih besar dari $\pm 1,96$ dan nilai $P$ Value 0,041 lebih kecil dari 0,05. Jadi dapat disimpulkan bahwa DAR berpengaruh negatif dan signifikan terhadap PBV, artinya semakin tinggi nilai DAR maka semakin rendah PBV. Demikian pula sebaliknya semakin rendah nilai DAR maka semakin tinggi PBV. Jadi hipotesis pertama yang menyatakan bahwa leverage berpengaruh terhadap nilai perusahaan diterima.

\section{Pengujian Hipotesis 2}

Pengujian hubungan variabel FAI terhadap PBV menunjukkan nilai O.S negatif sebesar 0,163 , nilai t-statistik sebesar 1,083 lebih kecil dari $\pm 1,96$ dan nilai $P$ Value 0,279 lebih besar dari 0,05. Jadi dapat disimpulkan bahwa fixed asset intensity tidak berpengaruh terhadap PBV, artinya tinggi atau rendahnya tingkat proporsi aset tetap terhadap total aset perusahaan tidak memiliki pengaruh terhadap PBV. Jadi hipotesis kedua yang menyatakan bahwa fixed asset intensity berpengaruh terhadap nilai perusahaan ditolak.

\section{Pengujian Hipotesis 3}

Pengujian hubungan variabel SIZE terhadap PBV menunjukkan nilai O.S positif sebesar 0,893, nilai t-statistik sebesar 3,254 lebih besar dari $\pm 1,96$ dan nilai $P$ Value 0,001 lebih kecil dari 0,05. Jadi dapat disimpulkan bahwa firm size berpengaruh positif dan signifikan terhadap PBV. Semakin besar ukuran perusahaan, maka semakin tinggi nilai PBV, sebaliknya semakin kecil ukuran perusahaan maka semakin rendah nilai 
PBV. Jadi hipotesis ketiga yang menyatakan bahwa firm size berpengaruh terhadap nilai perusahaan diterima.

\section{Pengujian Hipotesis 4}

Pengujian pengaruh variabel interaksi REV.DAR (perkalian antara revaluasi aset dengan DAR) menunjukkan nilai O.S positif sebesar 0,043, nilai t-statistik sebesar 0,285 lebih kecil dari $\pm 1,96$ dan nilai P Value 0,776 lebih besar dari 0,05. Jadi dapat disimpulkan bahwa revaluasi aset tidak memoderasi pengaruh DAR terhadap PBV. Jadi hipotesis keempat yang menyatakan bahwa revaluasi aset memoderasi pengaruh leverage terhadap nilai perusahaan ditolak.

\section{Pengujian Hipotesis 5}

Pengujian pengaruh variabel interaksi REV.FAI (perkalian antara revaluasi aset dengan FAI) menunjukkan nilai O.S positif sebesar 0,001, nilai t-statistik sebesar 0,004 lebih kecil dari $\pm 1,96$ dan nilai $\mathrm{P}$ Value 0,997 lebih besar dari 0,05. Jadi dapat disimpulkan bahwa revaluasi aset tidak memoderasi pengaruh FAI terhadap PBV. Jadi hipotesis kelima yang menyatakan bahwa revaluasi aset memoderasi pengaruh fixed asset intensity terhadap nilai perusahaan ditolak.

\section{Pengujian Hipotesis 6}

Pengujian pengaruh variabel interaksi REV.SIZE (perkalian antara revaluasi aset dengan SIZE) menunjukkan nilai O.S negatif sebesar 0,241, nilai t-statistik sebesar 0,897 lebih kecil dari $\pm 1,96$ dan nilai P Value 0,370 lebih besar dari 0,05. Jadi dapat disimpulkan bahwa revaluasi aset tidak memoderasi pengaruh SIZE terhadap PBV. Jadi hipotesis keenam yang menyatakan bahwa revaluasi aset memoderasi pengaruh firm size terhadap nilai perusahaan ditolak.

\section{Pembahasan}

\section{Pengaruh Leverage terhadap Nilai Perusahaan}

Leverage yang diproksikan dengan debt to asset ratio (DAR) berpengaruh negatif dan signifikan terhadap nilai perusahaan yang diukur dengan price to book value (PBV). Semakin tinggi rasio leverage, maka semakin rendah nilai perusahaan. Perusahaan dikatakan tidak solvabel apabila total hutang perusahaan lebih besar daripada total aset yang dimiliki. Hal tersebut membuat investor lebih berhati-hati berinvestasi di perusahaan dengan rasio leverage tinggi, hal ini dikarenakan semakin tinggi rasio leverage maka semakin tinggi pula risiko investasinya.

Sesuai hasil penelitian Sujoko dan Soebiantoro (2007) yang menyatakan bahwa leverage berpengaruh negatif terhadap nilai perusahaan. Dalam hasil penelitiannya menyebutkan bahwa jumlah hutang yang terlalu tinggi akan menimbulkan risiko financial distress, yang akan mengakibatkan nilai perusahaan mengalami penurunan. Hasil penelitian ini tidak sama dengan hasil penelitian Analisa (2011), Novari dan Lestari (2016) yang tidak berhasil membuktikan bahwa leverage memiliki pengaruh terhadap nilai perusahaan

\section{Pengaruh Fixed Assets Intensity terhadap Nilai Perusahaan}

Fixed asset intensity tidak berpengaruh terhadap nilai perusahaan, artinya tinggi atau rendahnya tingkat proporsi aset tetap dalam perusahaan tidak memiliki pengaruh 
terhadap nilai perusahaan. Walaupun peranan aset tetap dalam mendukung sebagian besar kegiatan operasional perusahaan cukuplah besar, tetapi hal tersebut tidak menjadi pertimbangan bagi investor untuk berinvestasi. Dalam hal ini, para investor lebih memilih menggunakan rasio-rasio keuangan lain dari perusahaan sebagai bahan pertimbangan dalam melakukan penilaian terhadap perusahaan. Sesuai hasil penelitian Azari dan Fachrizal (2017) yang menyatakan bahwa fixed asset intensity tidak berpengaruh terhadap nilai perusahaan. Namun tidak sama dengan hasil penelitian Dharmendra (2016) yang menunjukkan bahwa fixed asset intensity berpengaruh positif terhadap nilai perusahaan.

\section{Pengaruh Firm Size terhadap Nilai Perusahaan}

Firm size berpengaruh positif dan signifikan terhadap nilai perusahaan. Semakin besar ukuran perusahaan, maka semakin tinggi nilai perusahaan tersebut. Perusahaan besar memiliki kondisi yang cenderung lebih stabil sehingga menarik minat investor untuk memiliki sahamnya. Hal tersebut akan menyebabkan naiknya harga saham perusahaan di pasar modal. Hasil penelitian sejalan dengan Prasetyorini (2013), yang menyatakan bahwa firm size berpengaruh positif terhadap nilai perusahaan. Dalam hasil penelitiannya menjelaskan bahwa perusahaan besar akan memperoleh kemudahan untuk memasuki pasar modal, karena investor menangkap sinyal yang positif terhadap perusahaan. Hasil penelitian ini tidak sama dengan penelitian Hardian dan Asyik (2016) yang menunjukkan bahwa ukuran perusahaan tidak berpengaruh terhadap nilai perusahaan.

\section{Revaluasi Aset Memoderasi Pengaruh Leverage terhadap Nilai Perusahaan}

Revaluasi aset tidak memoderasi pengaruh antara leverage (DAR) terhadap nilai perusahaan $(\mathrm{PBV})$. Semakin tinggi rasio leverage menunjukkan semakin besar dana yang disediakan oleh kreditur. Semakin tinggi tingkat hutang perusahaan, maka semakin tinggi pula risiko perusahaan. Hal ini dikarenakan jumlah hutang yang terlalu tinggi

akan menimbulkan financial distress (Sujoko dan Soebiantoro, 2007). Ketika perusahaan melakukan revaluasi aset, tingginya biaya yang timbul untuk merevaluasi aset (biaya appraisal dan biaya pajak atas nilai revaluasi aset) akan menjadi beban perusahaan, yang akan mengurangi profitabilitas perusahaan. Perusahaan dengan tingkat hutang terlalu tinggi ditambah dengan biaya yang harus dikeluarkan untuk merevaluasi aset, kondisi tersebut justru akan semakin meningkatkan risiko perusahaan.

\section{Revaluasi Aset Memoderasi Pengaruh Fixed Asset Intensity terhadap Nilai Perusahaan}

Revaluasi aset tidak memoderasi pengaruh antara fixed asset intensity terhadap nilai perusahaan (PBV). Perusahaan dengan intensitas aset tetap yang besar menunjukkan besarnya proporsi aset tetap dibandingkan total aset perusahaan. Semakin besar proporsi aset tetap suatu perusahaan, maka ketika perusahaan melakukan revaluasi aset, biaya pajak yang muncul atas nilai revaluasi juga akan semakin besar. Biaya yang timbul tersebut akan mengurangi laba perusahaan, akibatnya nilai perusahaan akan menurun. 


\section{Revaluasi Aset Memoderasi Pengaruh Firm Size terhadap Nilai Perusahaan}

Revaluasi aset tidak memoderasi pengaruh antara firm size terhadap nilai perusahaan (PBV). Perusahaan besar identik dengan perusahaan dengan pofitabilitas tinggi. Perusahaan besar akan menghindari pelaporan profitabilitas yang tinggi untuk menurunkan tekanan politik dari pihak-pihak eksternal (pemerintah dan serikat pekerja). Revaluasi aset yang mengakibatkan peningkatan nilai aset dapat menurunkan pelaporan laba perusahaan, sehingga perusahaan mendapatkan manfaat pajak atas peningkatan biaya depresiasi. Namun biaya yang muncul ketika perusahaan melakukan revaluasi aset juga akan menjadi pengurang laba perusahaan. Hal tersebut akan menunjukkan bahwa secara finansial performance, laba perusahaan mengalami penurunan sehingga akan mengakibatkan turunnya nilai perusahaan dimata investor.

\section{PENUTUP}

\section{Simpulan}

Penelitian ini bertujuan menganalisis pengaruh leverage yang diproksikan dengan debt to asset ratio, fixed asset intensity dan firm size terhadap nilai perusahaan yang diproksikan dengan price to book value dengan revaluasi aset sebagai moderasi. Hasil penelitian menunjukkan bahwa debt to asset ratio (DAR) berpengaruh negatif signifikan terhadap nilai perusahaan. Pada perusahaan manufaktur yang terdaftar di BEI tahun 2015-2016, semakin besar perusahaan menggunakan pendanaan dari hutang maka nilai perusahaan akan semakin menurun. Hal tersebut dikarenakan dengan tingkat hutang yang tinggi, risiko perusahaan juga akan semakin tinggi, sehingga mengakibatkan menurunnya nilai perusahaan.

Fixed asset intensity tidak berpengaruh terhadap nilai perusahaan. Tinggi atau rendahnya tingkat proporsi aset tetap dalam perusahaan tidak memiliki pengaruh terhadap nilai perusahaan. Walaupun peranan aset tetap dalam mendukung kegiatan operasional perusahaan cukuplah besar, tetapi hal tersebut tidak menjadi bahan pertimbangan investor dalam berinvestasi. Firm size berpengaruh positif signifikan terhadap nilai perusahaan (PBV). Semakin besar ukuran suatu perusahaan, maka akan semakin tinggi nilai perusahaan tersebut. Perusahaan yang besar cenderung memiliki kondisi yang lebih stabil, sehinga akan menarik minat investor untuk memiliki saham perusahaan, yang akan menyebabkan naiknya harga saham perusahaan di pasar modal.

Revaluasi aset tidak memoderasi pengaruh leverage terhadap nilai perusahaan. Hubungan positif interaksi revaluasi aset dan debt to asset ratio (DAR) menunjukkan bahwa revaluasi aset memperkuat hubungan antara debt to asset ratio terhadap price to book value. Revaluasi aset tidak memoderasi pengaruh fixed asset intensity terhadap nilai perusahaan. Hubungan positif interaksi revaluasi aset dan fixed asset intensity menunjukkan bahwa revaluasi aset memperkuat hubungan antara proporsi aset tetap terhadap price to book value. Revaluasi aset tidak memoderasi pengaruh firm size terhadap nilai perusahaan. Hubungan negatif interaksi revaluasi aset dan firm size menunjukkan bahwa revaluasi aset memperlemah hubungan antara ukuran suatu perusahaan terhadap price to book value.

\section{Implikasi Manajerial}

Manajemen perusahaan dapat memilih menggunakan eksternal financing (hutang) dibandingkan internal financing (laba ditahan) yang dimilikinya dengan tujuan 
untuk memperbesar perusahaan. Dengan ukuran perusahaan yang semakin besar maka tujuan untuk memaksimalkan nilai perusahaan akan lebih bisa tercapai, asalkan pengambilan hutang dimaksud dilakukan secara feasible dengan mempertimbangkan debt ratio perusahaan.

Ketika perusahaan memutuskan untuk melakukan revaluasi atas aset tetapnya, manajemen juga harus memperhitungkan manfaat dan dampaknya terhadap perusahaan. Keputusan yang diambil oleh pihak manajemen sebaiknya tidak menimbulkan konflik kepentingan dengan para pemegang saham. Karena ketika terjadi konflik kepentingan, maka tujuan perusahaan untuk memaksimalkan nilai perusahaan akan sulit tercapai.

\section{Keterbatasan Penelitian}

Penelitian ini tidak berhasil membuktikan peranan revaluasi aset dalam memoderasi pengaruh leverage, fixed asset intensity, dan firm size terhadap nilai perusahaan, sesuai dengan signaling theory. Hal ini dikarenakan biaya pelaksanaan revaluasi yang cukup tinggi akan mengurangi profitabilitas perusahaan, yang mengakibatnya financial performance menurun.

Variabel independen yang digunakan dalam penelitian ini adalah debt to asset ratio, fixed asset intensity, firm size dan variabel moderating revaluasi aset menunjukkan nilai R-Square 0,434 terhadap nilai perusahaan. Nilai koefisien determinasi menunjukkan bahwa $43,4 \%$ dari variabilitas nilai perusahaan yang dapat dijelaskan oleh variabel independen dan moderating yang digunakan dalam penelitian, yang artinya masih terdapat pengaruh variabel lain yang belum diteliti.

\section{DAFTAR PUSTAKA}

Analisa, Yangs. 2011. Pengaruh Ukuran Perusahaan, Leverage, Profitabilitas, dan Kebijakan Dividen Terhadap Nilai Perusahaan. E-jurnal Universitas Diponegoro.

Azari, T M Rizki dan Fachrizal. 2017. Pengaruh Asimetri Informasi, Profitabilitas, dan Leverage Terhadap Nilai Perusahaan Pada Perusahaan Manufaktur. Jurnal Ilmiah Mahasiswa Ekonomi Akuntansi (JIMEKA). Vol 2 No 1.

Azouzi, M Ali dan Jarboui, Anis. 2012. The Evidence Of Management Motivation to Revalue Property Plant and Equipment in Tunisia. Journal of Accpunting and Taxation. Vol 4 (2).

Brigham, Eugene.F dan Joel F. Houston. 2010. Dasar-dasar Manajemen Keuangan. Edisi 11. Jakarta: Salemba Empat.

Courtenay, M. Stephen dan Cahan, F Steven. 2000. Value Relevance of Mandated Comprehensive Income Disclosures. Journal of Business Finance and Accounting. Vol 27. 
Dharmendra. 2016. Pengaruh Leverage, Ukuran Perusahaan, Fixed Asset Intensity dan Investment Opportunity Terhadap Nilai Peusahaan dengan Revaluasi Aset Sebagai Variabel Moderating. Jurnal Akuntansi UNESA. Vol 2 No.2.

Firmansyah, Egy dan Erly Sherlita. 2012. Pengaruh Negosiasi Debt Contrats dan Political Cost Terhadap Perusahaan Untuk Melakukan Revaluasi Aset Tetap (Studi Empiris Pada Perusahaan Yang Terdaftar di BEI Tahun 2010). Jurnal Bisnis dan Bisnis.

Hardian, Ananda Putra dan Asyik, Nur Fadjrih. 2016. Kinerja Keuangan dan Ukuran Perusahaan Terhadap Nilai Perusahaan. Jurnal Ilmu dan Riset Akuntansi. Vol 5 No 9.

Katuuk, Yolanda C. 2013. Analisis Perencanaan Pajak Melalui Revaluasi Aktiva Tetap Pada PT Angkasa Pura I (Persero) Bandar SAM Ratulangi. Jurnal EMBA. Vol 01 No 3.

Khairati, Adzkya. 2015. Pengaruh Leverage, Firm Size, dan Fixed Asset Intensity terhadap Keputusan Perusahaan Melakukan Revaluasi Aset Tetap. Universitas Bung Hatta Padang.

Myers, S and Maljuf. 1984. Corporate Financing and Investment Decision When Firms have Information Investor Do Not Have. Journal of Finance Economics. 13.

Novari, Putu Mikhy dan Lestari, Putu Vivi. 2016. Pengaruh Ukurann Perusahaan, Leverage dan Profitabilitas Terhadap Nilai Perusahaan Pada Sektor Properti dan Real Estate. E-Jurnal Manjemen Unud. Vol 5 No 9.

Piera, Frank Missioner, 2007. Motives for Fixed Asset Revaluation : An Emperical Analysis with Swiss Data. The International of Accounting 42.

Prasetyorini, Bhekti Fitri. 2013. Pengaruh Ukuran Perusahaan, Leverage, Price Earning Ratio dan Profitabilitas terhadap Nilai Perusahaan. Jurnal Ilmu Manajemen. Vol $1(1)$.

Pratama, I.G.B Angga dan Wiksuana, I.G.B. 2016. Pengaruh Ukuran Perusahaan dan Leverage Terhadap Nilai Perusahaan dengan Profitabilitas Sebagai Variabel Mediasi. E-Jurnal Manajemen Unud. Vol 5 No 2.

Rahayu, Maryati dan Sari, Bida. 2018. Faktor-Faktor Yang Mempengaruhi Nilai Perusahaan. Ikraith-Humaniora. Vol 2. No 2.

Seng, Dyna dan Su, Jiahua. 2010. Managerial Incentives Behind Fixed Asset Revaluation : Evidence from New Zealand Firms. International Journal of Business Research. Vol 10 No 2.

Suharli, Michelli 2006. Studi Empiris Terhadap Faktor Yang Mempengaruhi Nilai Perusahaan Pada Perusahaan Go Public di Indonesia. Jurnal Maksi. Vol 6 (1). 
Sujoko dan Soebiantoro, Ugy. 2007. Pengaruh Struktur Kepemilikan Saham, Leverage, Faktor Intern dan Faktor Ekstern Terhadap Nilai Perusahaan. Jurnal Manajemen dan Kewirausahaan. Vol 9 No 1. 